\title{
Foreword: membership and its instabilities
}

\section{Saskia Sassen}

I think of citizenship as an incompletely theorized contract between the rights-bearing individual and her state. It is in this incompleteness of citizenship that lies the possibility for its long and mutating life. There is room for making and remaking "the" citizen: and this includes making by those who do not belong - whether the foreigner outside or the foreigner inside a country.

Historically, outsiders have been a key factor for ensuring this incompleteness of citizenship. They are the ones who have subjected the institution to new types of claims across time and place, whether it is non-property owners in England's 1800s claiming rights to citizenship or gays and lesbians in 2000 claiming the same rights as other citizens. Women, minoritized citizens, asylum seekers, immigrants, all have contributed to expand the rights of all citizens in often multi-generational trajectories. They may not have gained much power in this process, but their powerlessness became complex - they made a history, a politics. Making by the powerless has a very different temporality from that of making by the powerful. It can take decades and even centuries, but in the long run of history the powerless are always the majority. And when their demands for expanded inclusions succeeded, they strengthened the institution of citizenship partly by making it more complex and incomplete, a mix that enables adjustments in the meaning of membership across diverse historical epochs and their specific modes of making the spaces for belonging.

Today the meaning itself of the national state and national membership are becoming unstable, and either neutralize nationhood or distort it into a visceral pre-political passion. The traditional borders of the modern interstate system became and 
continue to be a critical and marking feature for membership and a key to the debate about immigration.

What is not sufficiently worked into the debate is that the traditional interstate border, with all its practical and formal variability, is increasingly just one element in a larger emergent operational space for human mobilities that took off in the 1980s. At the high end we have seen the formation of new types of geographies of centrality that cut across old divides - North/South, East/West - and across interstate borders of all sorts. One enabling tool for these new types of geographies of privilege is the proliferation of specialized visas enabling firms to hire what are de facto immigrant workers but are pointedly referred to as "foreign professionals".

These are bordered spaces that cut across formal interstate borders. But they are themselves bordered via a range of newly developed instruments and capabilities, as I document elsewhere (Sassen 2014). And their borders are mostly extremely tight - no trafficker can take you across those borders. They include an enormous variety of flows. At one end, they include the private financial trading networks that are estimated to account for up to $70 \%$ of financial trading worldwide according to the US Federal Reserve Bank, which refers to them as "dark pools in finance". Neither the state nor existing national law plays much of a role in these types of spaces.

At the other end from finance, perhaps, is the WTO Mode 4 stipulation that gives workers a range of formal portable rights recognized in all signatory countries when a firm hires through the treaty. This is the making of a privileged subject with portable rights. We can learn from this. It is a possibility not envisaged in most discussions on immigration. But (almost) all immigrants are citizens of some country, a fact forgotten in the language of illegality - there is no such entity as an illegal human being. The challenge is to make some of the basic rights portable, as we have done for professionals.

More informally for today's mobile global class of the very rich, citizenship or formal state-authorized membership has little meaning - they do not need it to gain access to foreign national territories. Nor does it matter that much anymore for the immobile global class of dispossessed for whom citizenship is beginning to matter less and less; it gives them few rights and barely a platform 
for claim making. In these cases the foreigner has far more rights to place than the native. As I have documented elsewhere (Sassen 2008: chapter 6), citizens are losing rights in Western neoliberalized countries and economic corporate actors are gaining rights. Ironically, it is the claims by those who have barely been recognized in law - a broad mix of minoritized subjects, including immigrants and refugees - that have given new life to the meaning of citizenship. And historically Europe, especially, has shown us how the claims by outsiders for access to hospitals, schools, transport and more, contributed to strengthen the publicness of such facilities, thereby also benefitting citizens. But these victories are also under major attack in just about all Western countries. One question this raises is whether the current influx of refugees and migrants might serve once again to strengthen the publicness of major facilities in the long run (even if not immediately).

Are we seeing emergent meanings of membership and foreignness that destabilize our inherited meanings? Yes, and that is good because it brings new life to old or tired meanings. Sovereignty and territory remain key features of the international interstate system. But some of their components have been reconstituted and partly displaced onto other institutional arenas outside the state and outside the framework of national territory. From where I look at it (Sassen 2008), sovereignty has actually been partly decentred and territory partly denationalized even as political speech about them is more nationalist that it has been in a long time.

And this emergent reality at ground level will eventually alter the formal framings. We see elements of these types of ironic shifts across history. We see it today, for instance in the tension between having an open European space for economic flows that benefits above all the large corporations (and ironically the new refugees entering Europe) and the anxiety about being overwhelmed by refugee flows which led Sweden and Denmark in January 2016 to announce their decision to reinstate passport controls, a move that is detrimental to the corporate economy. It is out of such incompatible preferences that new modes of membership can arise, for good or for bad.

The interesting and, I would argue, historically strategic role of "the foreigner" - especially the disadvantaged poor immigrant and asylum seeker - is to generate claims for an expanding domain of the public good because it is their space for survival. The growing 
numbers of citizens who are losing ground given the new politics of "austerity" can also benefit from these claims by the outsiders, because they are becoming outsiders in their own countries.

Does the fact that anti-foreigner hatreds can coexist with the partial denationalizing of political membership tell us something about the historical role of the outsider?

In the past, the reasons for migrants coming to Europe and their origins differed from the reasons today. But the fact is that all current major European countries have taken in immigrants for centuries (Sassen 1999). And historical demography shows that most European nation-states have succeeded in incorporating foreigners over the centuries, even if these often started as brutal processes of maltreatment and exclusion. Today's French or Dutch, Viennese or Berliners, have a far higher incidence of foreign-born parents and grandparents, let alone older generations, than their rhetoric suggests.

Can we learn something from this history of multiple microintegrations alongside often murderous hatred of the outsider?

It is a fact that the immigrant groups of the past are today reasonably well absorbed, notwithstanding their differences. They have given us many of today's citizens. They are not at issue in today's debates. But in their time, they were the issue.

Anti-immigrant sentiment and attacks happened in each of the major immigration phases in all European countries (Sassen 1999). No labour-receiving country managed to avoid such hatreds of the foreigner, even when the foreigner was the same phenotype, religion or culture as the native - in short, even when the outsider was basically your cousin. No European country has a spotless record not Switzerland, with its long admirable history of international neutrality and not even France, one of the countries more open to immigrants, refugees and exiles. French workers killed Italian workers in the salt mines in the 1800s and objected to German and Belgian workers hired for Haussmann's rebuilding of Paris, in both cases invoking that they were the wrong types of Catholics.

History and demography suggest that those fighting for incorporation in the long run won, even though only partly. The "wrong Catholic" of yesterday's Europe still lives on dressed in a variety of new identities: in many ways the "wrong Catholic" is today the newly arrived Muslim. But what the past does tell us is that we fool ourselves if we think that differences of phenotype, religion and 
culture are the issue, and that these are obstacles built in stone and hence insurmountable. Migration hinges on a move between two worlds, even if within a single region or country - such as East Germans moving to West Germany who were seen as a different ethnic group and one with undesirable traits. Misplaced fear and prejudice are key players and so is today's European "austerity" politics, one that benefits the rich corporate sector and hurts the middle and working classes, who then see in the foreigner yet another threat.

Social membership takes time, and struggle. But it can eventually feed into more formal meanings of membership. At its best, our diversities, our foreign-ness, feed into dynamics that value this complexity of membership and its inevitable incompleteness.

\section{REFERENCES}

Sassen, Saskia (1999). Guests and Aliens. New York: New Press.

Sassen, Saskia (2008). Territory, Authority Rights: From Medieval to Global Assemblages. Princeton, NJ: Princeton University Press.

Sassen, Saskia (2014). Expulsions: Brutality and Complexity in the Global Economy. Cambridge, MA: Harvard University Press/Belknap. 